\title{
MANAGEMENT ETHICAL CHALLENGES IN THE TIME OF CRISIS WITH REGARD TO PHILOSOPHICAL CONSIDERATIONS OF JÓZEF TISCHNER
}

\author{
Anna KOCHMAŃSKA ${ }^{1 *}$, Izabela MARSZALEK-KOTZUR ${ }^{2}$ \\ ${ }^{1}$ Silesian University of Technology, Zabrze; Anna.Kochmanska@polsl.pl, ORCID: 0000-0002-6243-8687 \\ ${ }^{2}$ Silesian University of Technology, Zabrze; Izabela.Marszalek-Kotzur@polsl.pl, \\ ORCID: 0000-0002-8426-0170 \\ * Correspondence author
}

Purpose: The aim of the article is to show the ethical challenges of a modern manager in times of crisis and how to deal with them in the context of the original concept of human respect for ethical values, developed by Józef Tischner.

Design/methodology/approach: In-depth literature analysis was used in both organizational issues and philosophical texts.

Findings: They showed that in the case of organization, along with literal records, the key issue is to respect human dignity and develop human self-awareness. The focus was primarily on the issue of management's responsibility for implementing ethical behavior in the organization, and pointing to the risk of crossing the border, which leads directly to human exploitation.

Social implications: The presented theses may encourage the reader for further reflection on the issue of the mechanism of human behavior and may be very helpful in creating ethical attitudes of employees, and as a consequence may have a positive impact on the functioning of modern enterprises.

Originality/value: An innovative aspect of these considerations is the change in the perception of an employee as a work subject from an only economic to axiological perspective and an indication of those actions of the managerial staff that will allow employees to identify with the organization in terms of the professed value system.

Keywords: Organizational culture, ethical manager, code of ethics, values, work.

Category of the paper: Literature review.

\section{Introduction}

The realm of modern enterprises functioning has changed dramatically within the past few months. The growing threat caused by the pandemic has led to the temporary closure of many of them and, consequently, their significant financial instability. Many employees found 
themselves in a serious risk of losing their jobs. Constant fear and uncertainty in the context of future employment undoubtedly lead to a deterioration of the atmosphere and the collapse of the value system. An important question can be asked here, namely, what can we do to rebuild this system?

The top management will play a key role in the whole process. By transforming organizational culture, changing ethical codes (in which even greater emphasis will be placed on respecting employee rights) or innovative socialization processes, the company will clearly signal what is its priority at that time. However, this is only the first step to success. One should go further in these actions to lead to a situation when the declared values will be identical to the professed values. Therefore, the purpose of these considerations will be on the one hand to show the ethical challenges of managers in creating a new organizational reality, based primarily on ethical values, and on the other hand to identify those activities that will make (as aforementioned) the employees fully identify with them. How to absorb values to identify with them? In this regard, the philosophical considerations of Józef Tischner, who developed the original concept of work ethics, can be of a great help. The originality of the concept lies in exposing the key assumptions of work ethics, which are not based on the formulation of norms, but on the process of changing the consciousness of a working person. Tischner's texts, although written in the era of political and economic changes in Poland, strike with their timeliness, especially today, when in the face of a pandemic, man has become helpless and uncertain about their existential tomorrow.

\section{Determinants of business ethical activity}

In order to create an organizational culture with full conviction and commitment, employees in top management positions should represent a very high level of ethical values, and their value system should be consistent with the value system that the organization adheres to. The diverse range of selection techniques such as interviews, integrated assessment or a wide range of psychological tests (for example, skills, abilities, those based on work) allows you to identify the desired characteristics. As A. Rakowska emphasizes, "loyalty and ethics are particularly important in new models of organizations based on mutual trust. Managers should act morally and be responsible for their actions" (Rakowska, 2007, p. 79).

Attention to ethical behavior in management is also drawn by J. Klimek, who was arguing that "the key task of the management is to create such structures within enterprises and such incentive systems that can reasonably reconcile the interests of the owners, employees and customers. A company cannot be treated as a charity that solves social problems, educational problems, etc. Social responsibility in business consists of maximizing profits while maintaining ethical rules of economic activities. It is based on the belief that modern companies 
must look for the way of sustainable development including economic, ecological and social dimension" (Klimek, 2014, p. 291).

K. Gadomska- Lila also refers to corporate social responsibility in times ofcrisis. The author stresses that "companiesshould not only step up their social responsibility activities, but also improve their initiatives. In particular, consistent and systemic action is needed to achieve the CSR concept corresponding to the country's current development challenges and specific macroeconomic conditions, including the effects of the economic downturn. To this end, it is useful to combine csr ideas with national, regional and local development programmes, clarifying the expectations of economic operators and defining actions conducive to the implementation of these expectations (e.g. innovation), as well as reducing barriers to the effectiveness of csr implementation (e.g. inconsistency of administrative procedures)" (Gadomska- Lila, 2012, p. 32).

In order to do so, cooperation with the surround is based on clear, transparent and, above all, ethical principles.

Pointing to the norms and values that an ethical manager should adhere to and transfer to the organizational ground, it is worth quoting the six golden rules of management's behavior. J. Gołuch refers to them in the article "Etiquette in business". They include (Goluch, 2000, p. 101):

1. "Righteousness. This concept includes fair conduct and being truthful.

2. Manners. The point is not to be selfish or surly towards your colleagues.

3. Personality. You should properly convey your own values to others, your pro-social attitudes and opinions.

4. Appearance. You should look as good as possible.

5. Respect for others. You should have an objective, distant attitude towards yourself. That's why you should try to look at yourself through the prism of others.

6. Tact. It means feeling the situation and understanding your subordinates".

G. Myśliwiec presents an interesting approach to business conduct ethics. It consists of a hierarchy of moral values, which should be an indicator of economic activity. This is shown in Figure 1.

Analyzing the values below, it can be concluded that ethical management is a huge challenge for the managerial staff. Meeting these requirements should begin with a clear definition of the company's priority of values in the form of a transparent code of ethics. 


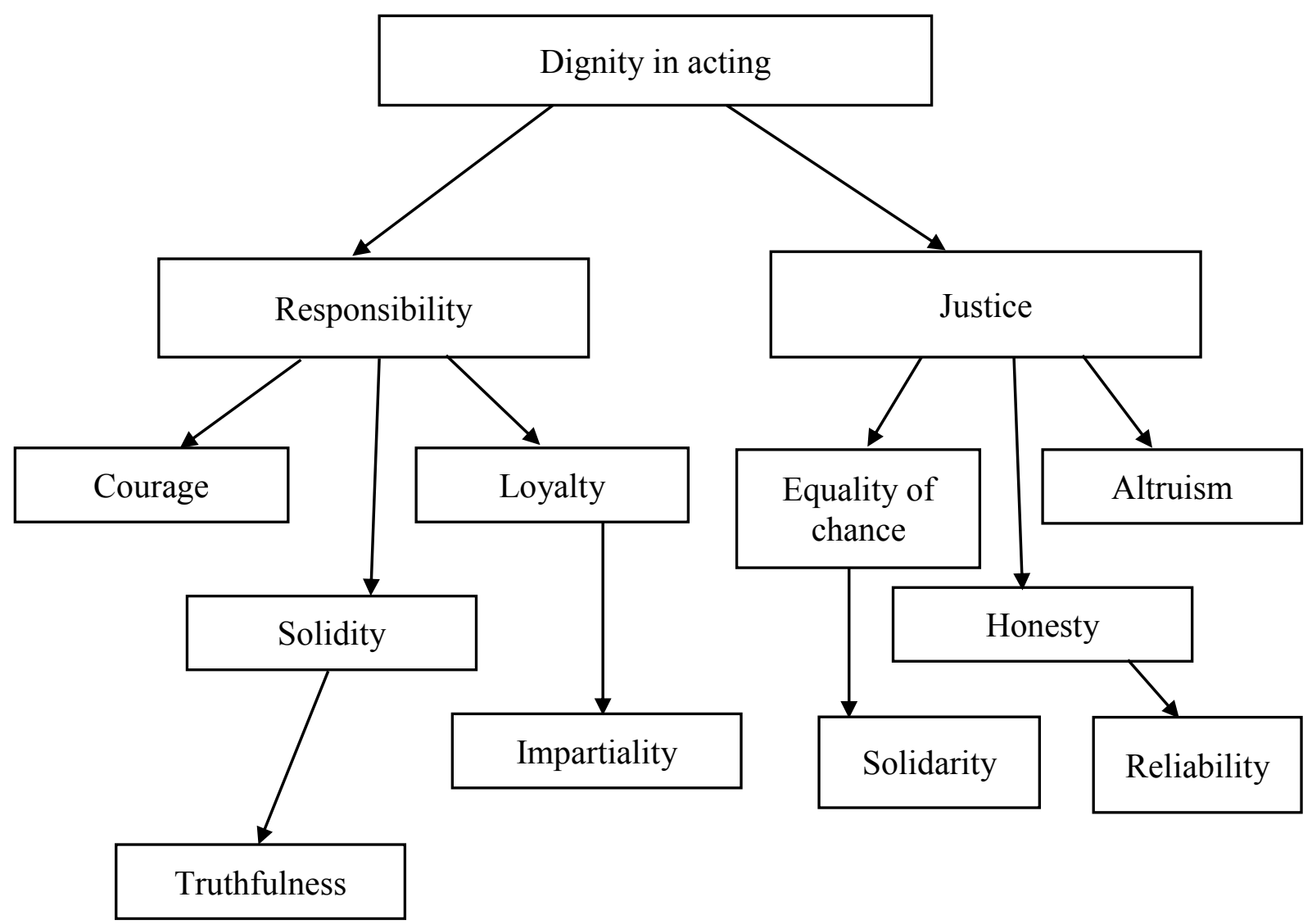

(Task fulfillment dimension)

(Aim and division dimension)

Figure 1. Moral values hierarchy. Source: Myśliwiec, G. (2007). Zarys etyki gospodarczej i zawodowej. Warszawa: DrukTur Sp. z o.o.

\section{The Code of Ethics as an element of organizational culture}

In the literature on the subject, the definition range of organizational culture is very wide. One can cite here even the interpretation of this concept by M. Raich and J. Klimek, who say that "when we talk about organizational culture, it is convenient to think of organization as a living organism. He must adapt to the environment (e.g. through science), has his own character (personality), has relations with internal and external institutions (e.g. ecology), has a history and path of development (evolution). Culture is all that people are and what people think" (Raich and Klimek, 2000, p. 127).

M. Kostera, in turn, claims that "culture is not a creation of nature, but of human communities, we receive it as a gift from others, from those who previously were participants of culture from us, like a layette" (Kostera, 2000, p. 20). 
Organizational culture researcher E. Schein believes that "culture is constantly repeated, kerified by our interaction with others and also shaped by our own behavior"' (Schein, 2010, p. 3).

When analysing the concept of organisational culture, it is worth noting the definition of G. Hofstede, who points out that "the culture of an organisation is a collective programming of the mind that distinguishes the members of one group or category of people from another" (Hofstede, 2000, p. 41).

The above mentioned definitions combine both the axiological and intentional nature of organizational culture, i.e. permanent focus on values. This is how its behavioral dream manifests.

A huge challenge for contemporary managers is the need to rebuild the organizational culture, adapting it to new, extremely difficult and demanding realities.

Starting this complex process (focused primarily on the employee and their needs including the need for security and stability, so important at the time of the pandemic), attention should be paid to documents that define specific norms and values. They are the benchmark for employees in various situations, thus explaining the emerging doubt and contentious issues of an ethical nature. The Code of Ethics is such a document.

The oldest ethical codes include the fifth century B.C. Hippocratic Oath. There you can find a collection of extremely important up to date postulates relating to the work of doctors (Pietrzkiewicz, 1997).

The second code is the Code of Bar Ethics, written by one of the greatest Roman speakers, the philosopher Cicero. Among other venerable codes we can also find codes of knights' ethics or teachers (Środa, 1995).

Contemporary ethical codes can be divided into four main groups (Hope, 2001):

- Professional ethical codes;

- Codes of ethics regarding areas of economic life;

- Industry ethical codes;

- Codes of companies and consortia.

In order for them to serve educational purposes, they must undoubtedly be very specific and comprehensible to all employees. In addition, when creating codes, it is necessary to know the employees' opinions regarding their expectations in this respect.

\section{Ethical imagination in the world of values}

It is worth emphasizing here, as Józef Tischner argues, that a normative document alone is not enough to develop a stable and based on a solid foundation system of values in the organization with which all employees can identify. One should strive for such a situation that 
values are not only empty declarations, but are professed values. Tischner claims that the mere acquisition of norms does not bring the expected result, because orders and prohibitions neglect the attitude of man to his own activity, i.e. responsibility, and are unable to develop human ability to distinguish good from evil, or sensitivity to the world of values (Tischner, 2000b). Ethics in the space of human work is no exception. According to the Cracovian philosopher, the concept of value is synonymous to the concept of good, which is the basis of all values, especially values rooted in the human being. Personal rights manifest themselves through ethical values (Tischner, 1993a). Therefore, the concept closely related to ethics is Good (Tischner, 1997, p. 141). Before a man implements norms, he must be able to recognize them, which is why, as Tischner states, "to manipulate the norm creatively, one must see human tragic. One must therefore allow the imagination to speak to see the result of its action. (...) the condition for understanding the norm is some intuition (sense) of value. Since what I have to do then is some value for me, and what I should avoid is an anti-value. Meeting the other man in his tragic opens our consciousness to the world of objective good and evil, objective values and anti-values - objective, because rooted in real human tragedies" (Tischner, 2002, p. 367). A more important matter of modern ethics is changing human consciousness rather than controlling man by means of norms. Tischner calls ethics the art of discovering what is bad and what is good at paticular moment. “(...) the main task of ethics is to accompany man on the path of their life and to show, as clearly as possible, among which values their fate is. When a person sees the world of values that surrounds them, they can formulate do's and don'ts, they can cope alone, and when necessary, they can also assess themselves" (Tischner, 2000a, p. 13). That is why, instead of setting norms, the Kraków philosopher suggests that current "ethical styles" should be formulated, having their source in the need to combat the forms of a particularly dangerous type of evil at a given time. In ethical thinking, says the Cracovian philosopher, it is a must to correctly read "signs of the times" and have good will to understand them (Tischner, 2002b). The management's responsibility cannot be overestimated at this time, because it determines the culture, or "ethical style" of the organization it manages. Just like Kant, Tischner emphasizes the importance of good will in human decisions and states that only it can be the foundation of ethics. If the motive for action is not a good will, for example of a manager, then even if his or her action is worth recognition, he or she does not yet reach the level of ethics, therefore the condition for all ethics is human good will (Tischner, 2008, p. 489).

\section{Work - interpersonal dialogue}

Analyzing the assumptions of ethics adequate to the behavior of employees in the organization space, one should ask the question about the essence of work, what the work really is today and what place it occupies in human life. What needs does it meet and how does it 
build a social community? Tischner believes that work is a natural good of man and a basic field in which human good will appear. According to the Cracovian philosopher, the work primarily serves to meet the basic needs of man, but also contributes to the development of his humanity and is a peculiar form of human being rooted in both the environment and the culture he creates and participates in. It is true in organizational culture as well. Man decides to take a job to meet various needs, but while working he interacts with other people. Then, as Tischner states, a working man suspends the need and enters into a dialogue with another working man. Through this dialogue, he works not so much out of necessity as out of good will, which gives the work a human face (Tischner, 2005b, pp. 36-37). Work understood as a dialogue means the exchange of views and experiences by people who occupy different places in time and space. Work, as the Cracovian philosopher states, is work for others, along with others, under the supervision of others. "When taking up a job, man accepts being interpenetrated by the presence of others. Through these touches, a person feels himself, experiences himself, understands himself. In this way, the chance to 'feel more human' opens up for him" (Tischner, 2005a, p. 97). Work dialogue is a special form of human conversation. Communication at work serves a primary purpose - life. Work serves life when it supports life and ensures its development, or gives life a deeper meaning (Tischner, 2005b, pp. 25-27).

Man carries his axiological self through life, that is, he understands himself as a value. Despite the awareness of all its numerous limitations and many weaknesses, it has the conviction that it is a value so valuable that one can even say, it is an irreplaceable value, worth recognition. However, his own conviction needs recognition from another person (Tischner, 2001, p. 15). Tischner, referring to the Hegelian concept of recognition, emphasizes that one's humanity results directly from the recognition flowing from the other person. This recognition not only enhances man, but also has a creative character. (Tischner, 2008, p. 7.)

What this recognition really is? Tischner is of the opinion that the ethical perspective of human development is defined by his dignity (Tischner, 2005b, p. 62). The sources of work dignity should be sought not in its objective dimension, but in the subjective dimension (Tischner, 2005b, p. 195). As the Cracovian philosopher argues, the subject of the work is a human person. The close relation between a person and work distinguishes an ethical point of view on work from an economic point of view (Tischner, 2005a, p. 96). Referring to the teaching of John Paul II, Tischner emphasizes that the basis for determining the value of human work is therefore not the type of activity performed, but the fact that it is performed by a person (Jan Paweł II, 1981, p. 6).

The fact that work concerns a human being and, as mentioned before, is a kind of interpersonal dialogue, makes human work a manifestation of some of his hopes. That is why there is a moment of trust in the work space. You always work with a colleague you trust. You also trust those who have planned work that they do not make you work without sense. If that were the case, the bonds of trust would be broken and a person would experience some kind of betrayal. Betrayal is the breaking of the bonds of trust (Tischner, 2005b, pp. 108-109). 


\section{Work exploitation - management ethical responsibility}

Betrayal in the workplace, Tischner notices, is directly linked to the concept of exploitation. The work itself is one of the natural burdens of man. As Tischner writes, "you have to carry it, this is what your fate is. The point is to avoid unnecessary pain - the one at the hands of others. The name 'exploitation' is used for this pain" (Tischner, 2005b, p. 23). The character of exploitation changes with social and economic changes. It is therefore worth considering what its essence is (Tischner, 2005b, p. 30).

Tischner distinguishes two basic relationships in the workplace. The first is the relationship between colleagues at the same level in the organization. The other is related to the basic work order (Marszałek, 2017). The work order depends on various objective factors that determine the directions of job selection (country's natural resources, climate, technological progress), and relations with the employer. The latter are important from the point of view of this research. The relationship with the employer is most often manifested as an employment contract, which gives rise to an exchange of services - a certain amount and quality of work in exchange for the promise of fair pay. In Tischner's conviction, if a mistake appears in the basic design, it means for ethics that a person, in this case an employer, a manager has gone astray. This may happen when a disturbance of the basic order occurrs, and as Tischner writes, "the situation when work seves the man turns to make the man serve the work" (Tischner, 2005b, pp. 31-32). As Tischner states, in such case there are disturbances in the basic structures of labor dialogue, which result in the rise of exploitation. One of the forms of exploitation described by Tischner is moral exploitation (Tischner, 2005b, pp. 31-32). Moral exploitation of work results in the moral disintegration of the entire work community, leading to a situation of lack of motivation to work, bitterness, various forms of inhibition, opportunism, and as Tischner writes, "prevents the realization of the creative joy of work" (Tischner, 2002b, p. 81). According to Tischner, at the level of consciousness of a working man there is a state of loss of authenticity at work and in the manner of being determined by work. Because the work has a thoroughly personal character (Tischner, 2002b, p. 81), exploitation means, as Tischner writes, that "a man has abused another man, treating him improperly. Hence, the painful sense of disappointment, the awareness of something done 'in vain', which is a foretaste of meaninglessness. Is it worth to sacrifice for anyone? Whoever exploits and abuses his work harms the goodness of human will. Exploitation despises good will, humiliates it, betrays it. It it a form of human treason. The exploited man feels like a betrayed man" (Tischner, 2005b, p. 37). Work without sense, regardless of what form it takes, harms the sense of dignity of working people, and is a form of betrayal (Tischner, 2005b, pp. 113-114). 
Tischner's observations show that the horizon of betrayal today is part of the human worldview. Sometimes treason is introduced into interpersonal relationships in a completely conscious way. In order to achieve this, as the Cracovian philosopher bitterly states, one's imagination - "the power of colorful presentation of many possibilities" is killed. The consciousness of independence and freedom is violated in order to take over the other person (Tischner, 2000b, p. 86). Instead of developing, work can become a killing of humanity, warns Tischner (Tischner, 2005a, p. 97).

According to Tischner, the acceptance of betrayal goes hand in hand with the daily struggle for the essence of human loyalty, sometimes acting by recalling orders and prohibitions of the law, speaking about them louder than usual. However, the problem of fidelity lies deeper than at the level of normativity. It's about how to rebuild hope in other people. Tischner argues: one can cheat on me, but this does not mean that I can also cheat on the other person, because man needs to have support in someone (Tischner, 2000b, pp. 88-89). According to Tischner, despite the fact that ethics and morality are kind of a deep sea of ambiguity, man will not get lost in it, when he is sure that the core of ethical experience is the experience of duty in the Kantian sense (Tischner, 1993b, p. 117). It seems that at this moment a specific ethical challenge and a field of great responsibility are opening up for the manager who wants to implement certain values in the company (Kuzior, 2017, p.78). According to Tischner, responsibility is the permanent presence of one man by the side of the other man, which is one of the manifestations of human loyalty. To be responsible means to be faithful (Tischner, 2000b, p. 95).

Any awareness of exploitation concerns above all the ethical awareness, a kind of man's moral self-knowledge, says Tischner. The Cracovian philosopher is convinced that a man can bear many physical loads, be able to suffer hunger, but cannot bear moral burdens. At the same time, moral suffering does not exclude bodily suffering. However, as Tischner emphasizes, the feeling of fatigue, tiredness and exhaustion, the threat of hunger, are accompanied by some burden difficult to bear, suffering soul and pain in the heart (Tischner, 2005b, p. 37). Moral oppression tightens the loop on humanity. Therefore, Tischner believes that every responsible person, at every workplace, should rebel against moral exploitation. The rebellion of conscience against the moral exploitation of work brings to the fore the matter of human dignity. As Tischner writes: "The grammar of relations between people is ethics and its principle - human dignity. That is why the rebellion against moral exploitation is not just a rebellion, it is a voice calling for faithfulness" (Tischner, 2005b, p. 38).

Human dignity has priority over work and pay. Dignity is neither pride nor ambition but a form of human freedom (Tischner, 2005b, pp. 113-114). To conclude, freedom is the basic human value. Ethics can begin with the value of human freedom. As Tischner states: "First it is the ethics of truth, then it becomes the property of itself. From this moment on, man is the subject of rights and obligations, he is responsible for himself" (Tischner, 2005b, pp. 171-172). Acquiring values by employees in the Tischnerian sense, can guarantee the ethical 
stability of the company and a feeling of elementary sense of crew security. Developing such a behavioral model is a long-term process and requires the involvement of many parties, but it seems possible.

\section{Conclusion}

It is a common knowledge, that work is always related to some kind of a crisis. Although crises take many forms, the laws that govern them seem to have some similarities. Therefore, the above-described actions of managers regarding the implementation of the principles of ethical behavior in organizations, especially in the perspective of an unexpected pandemic, could be supplemented with philosophical reflections on this topic. The main burden of responsibility for the progress of work, rests, of course, on the shoulders of entrepreneurs, not on ordinary employees, but above all else, the employee has the right to get the fair remuneration regardless of the state of the enterprise (Tischner, 2005b, p. 209). However, the economic factor is not the only one that poses a problem. Nowadays, the problem is not in the very structure of work, but in the hierarchy of values in which we exist. If work is to be a utilitarian value, then one should consider what place these values occupy in our system of values. They are necessary for everyone, but it is a mistake to perceive them as the only values worth human intervention, especially when it comes to the board of directors. Tischner notices that there is a place where "business matter" begins to serve what is "selfless" and asks whether the modern world is aware of it (Tischner, 2005b, p. 284). Perhaps the current crisis associated with the pandemic, a crisis that is actually just beginning, has become such a moment that requires drawing attention to this problem. Of course, as mentioned earlier, the company cannot afford the situation of transforming into a charity, but it has a huge scope to act in the matter of providing a working person with a basic sense of security and respect at the moment of "human poverty" as Tischner would describe it. Sometimes there is no need to take lofty actions to achieve the desired effect. As Tischner used to say, the awareness that "it is enough to do a little to change a lot" is essentially an ethical awareness (Tischner, 2005b, p. 262). Man's work is a manifestation of some of his hopes. That is why there is a moment of trust of hope in the workplace. And since work is a dialogue, recognition of truth is accmpanies mutual tolerance, understanding and exclusion of violence. Work as an integral element of social communication is a language and just like the language itself is subject to qualification, according to the true or false criterion. Man's work is a language spoken to another man, a language that can destroy or develop him (Tischner, 2000b, p. 74). However, you always work with a colleague you trust. Also, those who have planned work are trusted not to make us work without sense (Tischner, 2005b, pp. 108-109). 
Obviously, this research does not exhaust the whole range of problems associated with the current crisis that has affected working people. It also does not provide specific examples of managers' ethical challenges, as the title might suggest, but merely point to difficult ethical issues. Nevertheless, they are an incentive for a deeper reflection on the crisis that can generate human exploitation. And although it takes many forms, the key to eliminate its effects is the very possibility of their theoretical detection and description.

\section{References}

1. Gadomska-Lila, K. (2012). Społeczna odpowiedzialność biznesu w obliczu kryzysu gospodarczego. Studia i Prace Wydziału Nauk Ekonomicznych i Zarzadzania, Vol. 28, p. 32, http://bazhum.muzhp.pl/media/files/Studia_i_Prace_Wydzialu_Nauk_Ekonomicznych_i_ Zarzadzania/Studia_i_Prace_Wydzialu_Nauk_Ekonomicznych_i_Zarzadzania-r2012t28/Studia_i_Prace_Wydzialu_Nauk_Ekonomicznych_i_Zarzadzania-r2012-t28-s2335/Studia_i_Prace_Wydzialu_Nauk_Ekonomicznych_i_Zarzadzania-r2012-t28-s2335.pdf, 07.06.2020.

2. Gołuch, J. (2000). Etykieta w biznesie. In: J. Jarco (ed.), Biznes i menedżer. Problemy naszych czasów (p. 101). Wrocław: Wydawnictwo Wyższej Szkoły Zarządzania.

3. Hofstede, G. (2000). Kultury i organizacje. Zaprogramowanie umystu. Warszawa: PWE.

4. Hope, E. (2001). Rola kodeksów etycznych w procesie instytucjonalizacji etyki. In: J. Kubka (ed.), Etyczne podstawy kultury biznesu (pp. 98-102). Gdańsk: Politechnika Gdańska.

5. Jan Paweł II (1981). Laborem exercens. Watykan.

6. Klimek, J. (2014). Etyka biznesu. Teoretyczne założenia, praktyka zastosowań. Warszawa: Wydawnictwo Difin SA.

7. Klimek, J., Raich, M. (2000). Wyzwania u progu XXI wieku. Katowice.

8. Kostera, M. (2000). Zarzadzanie personelem. Warszawa: PWE.

9. Kuzior, A. (2017). Etyka zarządzania i etyka biznesu. Zagadnienia podstawowe. In: A. Kuzior (ed.), Etyka biznesu i zrównoważony rozwój. Interdescyplinarne studia teoretyczno-empiryczne, $n r 2$ (pp. 69-85). Gliwice: Politechnika Śląska.

10. Legięć, J. (2012). Człowiek w filozofii pracy Józefa Tischnera. Kraków: Wydawnictwo Księży Sercanów.

11. Makowski, J. (2012). Wariacje Tischnerowskie. Warszawa: Świat Książki.

12. Marszałek, I. (2017). Praca jako kategoria aksjologiczna i agatologiczna. Tischnerowska propozycja etyki pracy. In: A. Kuzior (ed.), Wokót Podstawowych zagadnień współczesności. Zabrze: Etyka Biznesu i Zrównoważony Rozwój. Etyka biznesu i 
zrównoważony rozwój. Interdescyplinarne studia teoretyczno-empiryczne, $n r$ 2. Gliwice: Politechnika Śląska

13. Myśliwiec, G. (2007). Zarys etyki gospodarczej i zawodowej. Warszawa: DrukTur Sp. z o.o.

14. Pietrzkiewicz, T. (1997). Etyka zarzadzania rozwojem gospodarczym. In: J. Jarco, W. Gasparski (eds.), Etyka biznesu (p. 268). Warszawa: PWN.

15. Rakowska, A. (2007). Kompetencje menedżerskie kadry kierowniczej we wspótczesnych organizacjach. Lublin: Wydawnictwo Uniwersytetu Marii Curie- Skłodowskiej.

16. Schein, E.H. (2010). Organizational Culture and Leadership. San Francisco: Jossey-Bass, Inc., $\quad$ https://books.google.pl/books?id=Mnres2PIFLMC\&printsec=frontcover\&hl=pl $\# \mathrm{v}=$ onepage \&q\&f=false, 07.06.2020.

17. Sennett, R. (2010). Kultura nowego kapitalizmu. Warszawa.

18. Środa, M. (1995). Etyka zawodowa. Wiedza i Życie, nr 12, p. 10.

19. Szwed, A. (2014). Dlaczego dziś potrzebujemy filozofii pracy księdza Józefa Tischnera? In: A. Hennel-Brzozowska (ed.), Młody człowiek wobec pracy, wyzysku i bezrobocia. Perspektywy Fides et ratio. Kraków.

20. Tischner, J. (1985). Polska jest Ojczyzną. W kręgu filozofii pracy. Paris.

21. Tischner, J. (1991). Polski Młyn. Kraków: IWKM “Nasza Przyszłość”.

22. Tischner, J. (1993a). Nieszczęsny dar wolności. Kraków: Znak.

23. Tischner, J. (1993b) Spowiedź rewolucjonisty. Czytajac Fenomenologię ducha Hegla. Kraków: Znak.

24. Tischner, J. (1997). W krainie schorowanej wyobraźni. Kraków: Znak.

25. Tischner, J. (1999). Metamorfozy naszej pracy. Tygodnik Powszechny, 32.

26. Tischner, J. (2000a). Etyka solidarności. Kraków.

27. Tischner, J. (2000b). Świat ludzkiej nadziei. Kraków: Znak.

28. Tischner, J. (2002a). Myślenie wedtug wartości. Kraków: Znak.

29. Tischner, J. (2002b). Polski kształt dialogu. Kraków: Znak.

30. Tischner, J. (2005a). Idac przez puste błonia. Kraków: Znak.

31. Tischner, J. (2005b) Etyka solidarności oraz Homo Sovieticus. Kraków: Znak.

32. Tischner, J. (2008). Etyka a historia. Wykłady. Kraków: Colonel. 